\title{
MANAJEMEN SEKOLAH RAMAH ANAK PAUD INKLUSI
}

\author{
Alisa Alfina1, Rosyida Nurul Anwar2 \\ Universitas PGRI Madiun, Jawa Timur, Indonesia \\ Email : alisaalfina2017@unipma.ac.id¹,rosyidanurul@unipma.ac.id²
}

\begin{tabular}{l|l|l} 
Received: Februari 2020 & Accepted: Maret 2020 & Published: Maret 2020
\end{tabular}

\begin{abstract}
:
This study aims to understand the management of Child-Friendly Schools (SRA) of PAUD inclusive which was carried out at PAUD Cendekia Kids School and the All Kids Learning House in Madiun City, East Java. This research uses a qualitative approach with case study. The technique of collecting data is done through interviews, observation, and documentation. While the data analysis technique starts from the data display, data reduction, until drawing conclusions. The results showed that; First, PAUD Scholar Kids School and the All Kids Learning House have their respective characteristics in implementing inclusive PAUD management, by adjusting to the conditions of existing institutions. secondly, child-friendly inclusive PAUD management at Cendekia Kids School is in the process of finding shapes while the All Kids Learning House had a shape; third, the obstacles in trying to realize the SRA at Cendekia Kids School are different from those at the All Kids Learning House; fourth, the biggest obstacle to management is human resource management competence; fifth, the two institutions do not have legality as child-friendly PAUD, but in its implementation, it is already appropriate as a child-friendly inclusive PAUD.
\end{abstract}

Key words : Child-friendly schools, inclusive PAUD, PAUD educational management

\begin{abstract}
Abstrak :
Penelitian ini bertujuan untuk memahami tentang manajemen Sekolah Ramah Anak (SRA) PAUD inklusif yang dilaksanakan di PAUD Cendekia Kids School dan Rumah Belajar All Kids Kota Madiun, Jawa Timur. Penelitian ini menggunakan pendekatan kualitatif jenis studi kasus. Teknik pengumpulan datanya dilakukan melalui interview, observasi dan dokumentasi. Sedangkan teknik analisis datanya dimulai dari data display, data reduction, sampai pada penarikan kesimpulan. Hasil penelitian menunjukkan bahwa; Pertama, kedua PAUD memiliki ciri khas masing-masing dalam melaksanakan manajemen PAUD inklusif, dengan menyesuaikan pada kondisi lembaga yang ada; kedua, manajemen PAUD inklusif ramah anak di Cendekia Kids School dalam proses mencari bentuk, sedangkan Rumah Belajar All Kids telah memiliki bentuk; ketiga, kendala dalam upaya mewujudkan SRA di Cendekia Kids School berbeda dengan di Rumah Belajar All Kids; keempat, kendala terbesar manajemen adalah kompetensi manajemen sumber daya manusia; kelima, kedua PAUD belum ada legalitas sebagai PAUD ramah anak, namun dalam implementasinya sudah layak sebagai PAUD inklusif yang ramah anak.
\end{abstract}

Kata kunci : Sekolah ramah anak, PAUD inklusif, manajemen pendidikan PAUD 


\section{PENDAHULUAN}

Pendidikan merupakan sarana untuk mengembangkan minat dan bakat siswa sesuai dengan potensi yang dimilikinya (Wuryandani, 2018). Pendidikan ramah anak adalah menciptakan lingkungan belajar yang kondusif (condusive learning community), sehingga anak dapat belajar dengan efektif di dalam suasana yang memberikan rasa aman, penghargaan tanpa ancaman, dan memberikan semangat (Yulianto, 2016).

Sudah selayaknya sekolah nyaman dan menyenangkan bagi anak, agar proses dan hasil belajarnya maksimal (Sholeh, 2017); (Munif, 2016); (Hasan, 2016). Fakta di lapangan menunjukkan bahwa; siswa sering mendapatkan tekanan dan merasakan ketidaknyamanan ketika pergi ke sekolah (Subur, 2018). Kondisi sekolah yang tidak layak dan lingkungan yang tidak nyaman, menyebabkan anak rentan mendapatkan kekerasan, baik verbal maupun psikis (Putri, 2019).

Sekolah Ramah Anak (SRA) saat ini telah menjadi perhatian pemerintah. Hal ini didorong oleh komitmen bangsa Indonesia untuk memberikan hak perlindungan dan pendidikan, demi mewujudkan visi anak Indonesia yang sehat, cerdas, ceria, berakhlak mulia dan cinta tanah air (Siska, 2018). Selain itu, program sekolah ramah anak juga dilatarbelakangi oleh adanya proses pendidikan yang masih menjadikan anak sebagai objek, sehingga tidak jarang ditemukan bullying terhadap anak (Zumaroh, 2018).

Sekolah ramah anak dalam hal ini dipahami sebagai lembaga pendidikan yang memberikan semua hak anak secara penuh, serta pengelolaan kelas dan sekolah. Program Sekolah Ramah Anak menerapkan 3P, yaitu provisi, proteksi, dan partisipasi (Nuraeni, 2019). Hal ini dapat dipahami bahwa; sekolah ramah anak menjamin dan memenuhi hak anak dalam setiap aspek kehidupan secara terencana dan bertanggungjawab. Prinsip utama upaya ini adalah "non dsikriminasi" kepentingan yang terbaik bagi anak, hak untuk hidup, kelangsungan hidup dan perkembangan serta penghargaan terhadap pendapat anak (Muitasari, 2016).

Sekolah ramah anak diharapkan mampu menciptakan suasana belajar yang nyaman, tenang, sehingga mampu mengembangkan minat, bakat serta potensi yang dimiliki anak didik sesuai dengan perkembangan dan pertumbuhannya (Rahmawati, 2019). Sekolah diharapkan melaksanakan pembelajaran yang berkualitas, sarana prasarana memadai dan sumber daya yang berkualitas, baik dengan meningkatkan kualitas guru, moral, komitmen, status, pendapatan dan penghargaan, sehingga hasil pembelajaran akan berkualitas (Misnatun, 2006); (Mandiudza, 2013).

Penelitian survey yang dilakukan oleh Gustiana (2019) menemukan bahwa; PAUD di Kecamatan Sukasari Kota Bandung 70\% siap menuju sekolah ramah anak. Meski penelitian tersebut mewakili kondisi PAUD di satu wilayah, namun di lapangan masih banyak ditemukan kondisi PAUD yang memerlukan pembenahan di semua bidang, terutama pada manajemennya. Hal ini dibuktikan dari hasil akreditasi PAUD yang mendapatkan nilai baik (B) dan cukup (C), lebih banyak daripada yang mendapatkan nilai sangat baik (A). hal ini bisa menjadi salah satu acuan bentuk implementasi manajemen lembaga. 
Sejauh ini, sedikit yang meneliti manajemen sekolah ramah anak di PAUD, terutama manajemen sekolah ramah anak pada PAUD inklusi. Pendidikan anak usia dini inklusi adalah lembaga PAUD yang menerima secara terbuka anak berkebutuhan khusus (ABK) dan merupakan salah satu program sekolah ramah anak (Tirtayani, 2017). Selama ini, penelitian yang berkaitan dengan implementasi sekolah ramah anak baru sebatas pada satu program tertentu seperti; peranan orang tua yang dikemas melalui kegiatan parenting, ternyata mendukung terwujudnya sekolah ramah anak (Ndari, 2019), guru yang dilatih kompetensinya melalui Program Pelatihan Terintegrasi Berbasis Kompetensi (PPTBK) dengan materi pelatihan membuat Alat Permainan Edukatif (APE), menjadi salah satu cara untuk membuat guru mampu membuat APE sendiri yang sesuai dengan kebutuhan dan ramah anak (Mirawati, 2018).

Kebutuhan untuk mendapatkan model manajemen PAUD inklusi sekolah ramah anak mendesak dan penting, karena manajemen memiliki peranan dalam melakukan sebuah aktivitas, terutama dalam bidang pendidikan seperti sekolah ramah anak di PAUD inklusi. PAUD inklusi saat ini juga sudah mendapatkan perhatian dari pemerintah dan masyarakat, bahkan sudah digalakkan oleh pemerintah, namun implementasinya menurut hasil observasi pra penelitian masih belum maksimal.

Manajemen sekolah ramah anak PAUD inklusi belum banyak dikaji dalam satu lembaga inklusi, sehingga menjadi novelty penelitian ini. Focus penelitian ini adalah; bagaimana manajemen sekolah ramah anak pada PAUD inklusi di Cendekia Kids School (CKS) dan Rumah Belajar All Kids ?. Hasil penelitian ini diharapkan mendapatkan gambaran tentang manajemen sekolah ramah anak PAUD inklusi untuk bisa menjadi khazanah keilmuan yang berkaitan dengan manajemen sekolah ramah anak PAUD inklusi.

\section{METODE PENELITIAN}

Penelitian ini dilakukan pada dua lembaga PAUD yang ada di Kota Madiun, yaitu PAUD Laboratorium School Cendekia Kids School (CKS) dan Rumah Belajar All Kids. Kedua lembaga PAUD tersebut adalah PAUD nonformal dan inklusif. Penelitian ini menggunakan pendekatan kualitatif jenis studi kasus. Untuk mendapatkan gambaran manajemen kedua PAUD tersebut, peneliti ikut berbaur dalam aktivitas manajemen sekaligus melakukan pengamatan. Selain itu dilakukan juga wawancara dengan kepala sekolah dan guru. Data-data lain untuk menguatkan hasil penelitian diambil dokumendokumen tertulis yang bisa mendukung dan menguatkan penelitian. Semua data yang diperoleh diklasifikasikan, dibuat taksonomi dan direduksi disesuaikan dengan kebutuhan.

\section{HASIL DAN PEMBAHASAN}

\section{Pendidikan Anak Usia Dini (PAUD) Inklusif}

Cendekia Kids School (CKS) dan All Kids adalah lembaga PAUD nonformal inklusif. Lembaga pendidikan inklusif merupakan salah satu program Sekolah ramah anak yang diselenggarakan oleh pemerintah. Cendekia Kids School yang merupakan laboratorium sekolah Universitas PGRI Madiun 
berupaya mendukung program sekolah ramah anak dengan menyatakan diri secara terbuka sebagai lembaga PAUD inklusi. Sedangkan All Kids merupakan komunitas/ sekolah rumah sejak berdiri sudah menyatakan sebagai inklusif. Cendekia Kids School dan All Kids secara umum telah melaksanakan tiga basis sekolah ramah anak, karena memenuhi syarat lembaga yang sehat, memiliki lingkungan yang asri dan aman serta tidak ada kekerasan secara verbal maupun fisik.

Pada masa awal diberlakukannya inklusif di CKS, banyak muncul permasalahan berupa kekerasan fisik maupun verbal. Kekerasan berupa pertengkaran antar siswa ABK dengan regular yang menimbulkan cidera pada salah satu siswa. Pertengkaran tersebut membawa dampak pada perseteruan antara orang tua siswa dan mereka saling menyalahkan. Hal tersebut membawa dampak ketidaknyamanan di kelas terutama guru, karena orang tua mengintimidasi guru. Guru yang baru belajar menjadi guru di lembaga inklusi merasakan tekanan. Kasus ini menjadi pemikiran bagi CKS untuk kemudian mengambil tindakan memberikan pengembangan kapasitas guru. Sedangkan orang tua diadakan parenting dan dilibatkan pada kegiatan di sekolah. Program pengembangan kapasitas dan keterlibatan orang tua secara menyeluruh bisa mengurangi perilaku intimidasi terhadap guru.

Sedangkan di All Kids, tidak ditemui adanya kekerasan fisik maupun verbal. Wali murid dan lembaga memiliki visi dan tujuan searah. Jika terjadi kasus pertengkaran antar anak dalam proses penyelesaiannya didukung penuh oleh orang tua dalam penyelesaiannya dengan kesadaran bahwa hal tersebut sebagai bagian dari pembelajaran dan pendidikan. Orang tua dan guru di All Kids bekerjasama dalam proses pembelajaran dan komunikatif.

Proses sekolah ramah anak di PAUD salah satunya adalah bagaimana menanamkan karakter. Anak sebagai subyek dalam pembelajaran sekolah ramah anak diharapkan anak memiliki kebebasan dalam berkreasi dan bebas belajar dibawah lingkungan yang kondusif. Adanya peristiwa pertengkaran pada siswa sebenarnya merupakan kesempatan untuk menanamkan karakter. Penanaman karakter di sekolah memerlukan dukungan dan peranan keluarga dan lingkungan.

Menurut Undang-Undang Sikdiknas nomor 20 Tahun 2003, PAUD merupakan suatu upaya pembinaan yang ditujukan kepada anak sejak lahir sampai dengan usia 6 tahun untuk mempersiapkan anak dalam memasuki pendidikan selanjutnya, yaitu sekolah dasar. Pembinaan berupa pemberian rangsangan pendidikan dan pelatihan yang membantu perkembangan motorik, bahasa, kognitif, seni, sosial emosional dan spiritual. Keenam bidang yang dikembangkan tersebut merupakan landasan bagi pendidikan selanjutnya.

Secara teoritis, pendidikan inklusif merupakan lembaga pendidikan menerima dan memberikan kesempatan kepada semua peserta didik untuk mendapatkan pendidikan tanpa pengecualian bersama-sama belajar sesuai dengan usia atau teman sebaya (Rahim, 2016). Pada sekolah inklusif anak (siswa) reguler (normal) dan anak kebutuhan khusus belajar bersama dalam satu kelas dan sekolah regular (Baharun, 2018). Anak berkebutuhan khusus atau disebut disabilitas adalah anak yang memiliki hambatan berupa kelainan 
fisik, emosional, metal, social, emosional, dan atau anak yang memiliki potensi kecerdasan tertentu atau istimewa.

Pendidikan Inklusif menurut Friend \& Bursuck (2015) memiliki ciri-ciri bahwa; semua stakeholder di lembaga memiliki komitmen untuk bekerjasama dalam membantu semua siswa menemukan potensinya, kurikulum didesain khusus untuk semua siswa maupun untuk ABK, para professional menggunakan bahasa yang manusiawi dan memberikan julukan yang baik serta motivasi, menekan pada kemampuan dan mengubur kekurangan atau hambatan, memiliki layanan pendidikan khusus untuk semua atau sebaliknya, memiliki kegiatan belajar dan mengajar dirancang khusus untuk ABK serta dapat ditawarkan ke siswa regular, dan memiliki ruang atau lokasi pembelajaran yang bisa menunjang KBM untuk regular maupun ABK.

\section{Manajemen Sekolah Ramah Anak (SRA) PAUD Inklusif}

Sarana prasarana di CKS saat ini fasilitas umumnya sudah sangat memadai dan lengkap sebagai SRA. Namun saat meningkatkan kualitas layanannya menjadi inklusi pengaturan fasilitasnya memerlukan perombakan kembali terutama penyediaan ruang KBM khusus ABK, kamar mandi dan pengkondisian kelas, koridor dan Alat Permainan Edukatif (APE) outdoor. Salah satu kasus ketika ada siswa ABK yang mengalami hambatan berjalan saat menuju kelas dibantu atau harus merangkak melewati koridor kelas. Sebelumnya semua sepatu anak saat masuk ke kelas tidak dilepas. Namun dengan adanya ABK yang mengalami hambatan berjalan dan program untuk mandiri mencapai kelas harus merangkak, maka diberlakukan sepatu anak dilepas saat menuju kelas. Koridor sampai kelas yang bersih membuat ABK merangkak sampai kelasnya dengan nyaman.

Kasus kedua adalah kondisi kamar mandi, meski sudah terpisah antara laki-laki dan perempuan, desain kamar mandi adalah untuk orang dewasa dan belum ada fasilitas untuk ABK. Hal ini membuat kesulitan bagi anak-anak terutama ABK untuk berlatih mandiri ke kamar mandiri. Sementara untuk merombak kamar mandi memerlukan dana dan waktu. Ruang khusus untuk ABK juga belum tersedia di CKS. CKS melakukan perombakan tatanan kelas untuk bisa menyediakan ruang khusus ABK. APE out door untuk ABK belum bisa dipenuhi secara maksimal terkendala pada minimnya pengetahuan tentang APE outdoor yang sesuai dengan kondisi ABK dan sulitnya mendapatkan tempat untuk memesan secara khusus.

All Kids merupakan sebuah rumah berlantai dua. Semua fasilitasnya ruangan yang disediakan sama dengan rumah secara umum. ABK yang ada di All Kids saat penelitian ini ada yang mengalami hambatan berjalan dan harus memakai sepatu khusus supaya bisa berjalan. Semula untuk bisa mencapai lantai dua ABK harus dibantu ekstra dan dijaga. Namun, pada akhirnya tangga memiliki fungsi sebagai tempat berlatih dan terapi untuk ABK. Fasilitas permainan outdoor All Kids tidak ada, karena lingkungan All Kids berada di perumahan. 
Kegiatan outdoor dilakukan dengan memanfaatkan lingkungan yang ada di perumahan. Hal ini menjadi lebih nyaman bagi anak karena anak akrab dengan lingkungannya. Lingkungan yang aman menurut perseptif anak sebaiknya juga menjadi perhatian karena yang menjadi pengguna adalah anak (Jansson, Sundevall, \& Wales, 2016).

Dukungan dari Yayasan atau penyelenggara, kepala sekolah dan manajemen untuk mendapatkan sarana prasarana yang memadai sangat diperlukan. Di CKS dan All Kids, kondisi lingkungan dan kemampuan lembaga, mendorong lembaga untuk memiliki kreativitas dan inovasi supaya fasilitas yang ada bisa maksimal untuk menjadi penunjang KBM untuk ABK maupun anak regular.

Desain CKS ketika awal dibangun, bukan sebagai sekolah inklusif, sehingga saat mengembangkan lembaganya menjadi inklusif dalam proses perencanaan dan saran-prasarana perlu banyak inovasi dan kreatifitas. All Kids meski sejak awal sudah menerima $\mathrm{ABK}$, namun karena merupakan rumah belajar, maka sarana permanen tidak banyak mengalami perombakan. Saranaprasarana yang bersifat tidak permanen pengadaannya insindentil mengingat kondisi ABK yang masuk setiap tahunnya berbeda kebutuhannya. Sedangkan untuk pemeliharaan sudah sesuai dengan situasi dan kondisi. Secara umum manajemen sarana prasarana sudah bagus namun belum maksimal. Ini menjadi tantangan bagi CKS dan All Kids untuk lebih meningkatan kembali manajemen sarana dan prasarananya.

Kurikulum di CKS sedang dalam proses revitalisasi serta dalam proses dikembangkan menuju lembaga inklusi serta proses mencari bentuk kurikulum yang sesuai. Proses perombakan kurikulum kendala terbesar adalah pada kompetensi SDM, tidak adanya pendampingan dan minimnya pelatihan yang berkaitan dengan kurikulum, sehingga proses perombakan kurikulum terkesan lambat. Di All Kids kurikulumnya telah menemukan bentuk dan terus berkembang secara bertahap. Pengembangan kurikulum di All Kids literatur yang mempengaruhinya adalah Montessorie, multiple intelegence dan Glann Doman, sehingga dalam satu kelas uasianya heterogen. Guru di All Kids telah mendapatkan beberapa pelatihan yang berkaitan dengan inklusi dan terus mendapatkan pemantauan dan pengontrolan dalam proses KBM. Pengembangan kurikulum memerlukan literatur dan mengacu pada hasil pemetaan kebutuhan terutama kebutuhan siswa ABK disesuaikan dengan kondisi lembaga. Pendukung utama dalam pengembangan adalah kompetensi guru.

Tahapan selanjutnya dalam penyelenggaraan SRA adalah komitmen secara tertulis sebagai bukti bahwa SRA menjadi komitmen bersama antara sekolah dan stakeholder. Sehingga Sekolah dan stakeholder bersama-sama saling memberikan dukungan terbaik, moral, finansial dan sarana, dalam suka dan duka dan bertanggungjawab terhadap proses pelaksanaan SRA. Indikator komitmen tertulis ini adalah; pertama, memiliki kebijakan anti kekerasan yang di SK-kan; kedua, melaksanakan kebijakan,; ketiga, mencegah anak putus sekolah; keempat, komitmen menerapkan SRA; kelima, penyuluhan SRA; keenam, komitmen mewujudkan kawasan bebas rokok dan NAPZA; ketujuh, komitmen 
aman dari bencana; kedelapan, mengintegrasikan materi kesehatan, lingkungan hidup ke dalam proses pembelajaran; kesembilan, mengawasi semua kegiatan siswa; kesepuluh, kerjasama dengan orang tua mengenai riwayat kesehatan anak.

CKS dan All Kids sudah menyatakan diri sebagai PAUD inklusif. Secara tidak langsung ini merupakan pernyataan dan sebuah komitmen bagi siapa saja yang hendak menyekolahkan anaknya ke CKS dan All Kids, namun belum ada komitmen secara tertulis dan tim khusus. Di CKS bentuk lembaga yang inklusif telah ditekankan kepada orang tua siswa saat mendaftar, namun tidak menyeluruh. Front office saat menerima pendaftaran berganti-ganti dan belum ada SOP yang jelas berkenaan informasi yang harus diberikan. Secara umum penekanan inklusif disampaikan pada saat parenting sebelum tahun ajaran baru. Namun pada saat parenting tidak semua walimurid menghadiri. Kasus intimidasi orang tua terhadap guru di CKS saat adanya pertengkaran tidak sengaja antara siswa $\mathrm{ABK}$ dan regular menunjukkan belum adanya dukungan dan kerjasama antara orang tua dengan sekolah terhadap proses pembentukan karakter dan proses pembelajaran. Di All Kids tidak ada kendala atau protes dari orang saat terjadi permasalahan antar siswa. Bahkan orang tua akan selalu memberikan dukungan ketika terjadi permasalahan antar siswa untuk membuat siswa memahmi dan saling memaafkan. Di All Kids saat orang tua hendak mendaftar kembali diberi penguatan sebelum masuk, bahwa bentuk lembaganya adalah inklusif. Tidak tertulis tapi komitmen saling mendukung berjalan sesuai harapan karena komunikasi yang baik.

CKS dan All Kids memang memberlakukan lembaganya inklusi dan SRA. Namun perlu lebih ditingkatkan dengan melegalisasikan dan mengadministrasikan komitmen ini. Ini penting untuk menghindari adanya perselisihan dan hal-hal yang terjadi di luar kendali. Komitmen tertulis diperlukan untuk menjadi landasan hukum apabila terjadi permasalahan atau kendala dalam proses operasional, misalnya protes orang tua murid.

Brainware merupakan para pelaku atau Sumber Daya Manusia (SDM) yang terdiri dari guru, tenaga non guru, kepala sekolah, siswa, orang tua siswa, organisasi sekolah dan orang-orang di lingkungan sekolah. Guru menjadi kunci utama dalam melaksanakan pendidikan PAUD. Kendala SDM di sekolah inklusi adalah kemampuan SDM, kerjasama dengan orang tua siswa dan sulitnya mencari guru pendamping ABK menjadi permasalahan di CKS dan All Kids terutama guru pendamping ABK. Mengatasi minimnya guru pendamping ABK, CKS memanfaatkan mahasiswa UNIPMA yang magang dan menjalin kerjasama dengan kampus. Namun mahasiswa magang masih dalam proses belajar dan belum memiliki kompetensi yang diharapkan. Sementara guru kelas juga belum bisa mengarahkan bagaimana menjadi guru pendamping ABK. Seharusnya ada koordinator khusus yang menangani siswa ABK, sehingga guru pendamping ABK mendapatkan pendampingan dan pengarahan bagaimana mendampingi siswa ABK. Sedangkan di All Kids meski sering terjadi pergantian guru pendamping, guru utamanya sudah memiliki kompetensi menangani ABK dan bisa mengarahkan bagaimana mendampingi siswa ABK. 
Sekolah ramah anak yang menjadi misi utama di PAUD Cendekia Kids School dan All Kids akan mampu eksis apabila di kelola dengan baik dengan menggunakan pendekatan manajemen yang tepat guna. Manajemen merupakan aktivitas untuk mencapai tujuan dengan memanfaatkan manusia dan sumber daya yang ada (Boddy, 2008). Manajemen pendidikan diartikan sebagai aktivitas melaksanakan fungsi manajemen dengan memanfaatkan sumberdaya yang ada untuk mewujudkan visi dan misi pendidikan (Husaini Usman, 2011). Fungsi manajemen adalah perencanaan, pengorganisasian, pengarahan dan pengontrolan. PAUD secara umum bertujuan untuk memantik perkembangan dasar, potensi, membina dan membangun landasan pendidikan anak usia dini untuk menyiapkan anak menuju jenjang pendidikan berikutnya (Suyadi \& Ulfa, 2013). Dari uraian tersebut disimpulkan manajemen SRA PAUD adalah aktivitas melaksanakan fungsi manajemen dengan memanfaatkan sumberdaya yang ada untuk mencapai visi, misi dan tujuan SRA PAUD.

Sekolah Ramah Anak (SRA) menurut Peraturan Menteri Pemberdayaan Perempuan dan Perlindungan Anak Republik Indonesia Nomor 8 Tahun 2014 adalah sekolah yang sehat, bersih memiliki lingkungan yang menghargai hakhak anak dan perlindungan anak dari kekerasan, diskriminasi, dan perlakuan salah lainnya serta memiliki sumber daya pendidik yang terlatih. SRA berlaku untuk satuan pendidikan formal, informal, dan nonformal. SRA merupakan salah satu indikator pengembangan Kota Layak Anak (KLA).

Manajemen SRA PAUD inklusif merupakan perpaduan manajemen SRA, manajemen PAUD inklusi dan manajemen PAUD. Sederhananya manajemen SRA PAUD inklusif memiliki tiga unsur yang di manajemen, yaitu; pertama, hardware yaitu berkaitan dengan fisik lembaga dan sarana prasaran; kedua, sofware yaitu fitur-fitur SRA seperti komitmen tertulis, kurikulum dan program kegiatan; ketiga, brainware yaitu berkaitan pelaku seperti sumberdaya manusia, siswa, orang tua siswa dan lingkungan. Penelitian yang berkaitan dengan sekolah inklusi yang dilakukan oleh (Muazza, 2018) menunjukkan bahwa; infrastruktur dan sarana prasarana menjadi salah satu kendala dalam penyelenggaraan sekolah inklusi.

Hardware atau fasilitas sarana prasarana berdasarkan panduan SRA dan sekolah Inklusi, secara umum lembaga harus menyediakan ruang UKS (Usaha Kesehatan Sekolah), kamar mandi terpisah laki-laki dan perempuan, kantin sehat, memiliki, ruang Kegiatan Belajar Mengajar (KBM) yang bisa menunjang $\mathrm{ABK}$, infrasturktur yang aman dan sehat serta ruang konseling.

Prinsip pembentukan dan pengembangan sekolah ramah anak menurut panduan sekolah ramah anak adalah; pertama, sekolah tidak mendiskrimasi anak; kedua, semua pendidikan untuk kepentingan yang terbaik anak; ketiga, sekolah menciptakan lingkungan yang baik dan menghormati martabat anak, menjamin perkembangan setiap anak yang holistic dan integrative; keempat sekolah menghormati apapun pandangan anak yang mempengarui anak di lingkungan sekolah; dan kelima, sekolah memiliki pengelolaan atau manajemen yang baik, transparan, akuntabilitas (Kementerian Pemberdayaan Perempuan dan Perlindungan Anak, 2015). 
Lembaga pendidikan yang akan menerapkan sekolah ramah anak, setidaknya harus memenuhi 6 komponen persyaratannya, yaitu; pertama, komitmen secara tertulis sebagai kebijakan sekolah ramah anak; kedua, pembelajaran yang ramah anak; ketiga, pendidik dan tenaga kependidikan yang terlatih dan memahami kebijakan sekolah ramah anak; keempat, sarana dan prasarana yang mendukung sekolah ramah anak; kelima, partisipasi anak; keenam, partisipasi semua stakeholder. Sedangkan untuk implementasi manajemen keenam komponen sekolah ramah anak tersebut, melalui tahapan manajemen yang terdiri dari; pertama, persiapan; kedua, perencanaan tim pengembangan SRA menyusun rencana aksi tahunan untuk mewujudkan SRA yang terintegrasi dalam kebijakan; ketiga, pelaksanaan Tim Pengembangan SRA; keempat, pemantauan, evaluasi, dan pelaporan.

Sekolah ramah anak yang wajib diterapkan di lembaga pendidikan terdiri dari tiga konsep, pertama berbasis sekolah sehat yang lebih menekankan pada sarana dan prasarana, kedua sekolah ramah lingkungan yang menekankan pada lingkungan yang aman, nyaman, hijau dan asri, ketiga sekolah tanpa kekerasan yaitu sekolah terhindar dari perilaku kekerasan fisik maupun verbal (Utami, 2017). Kekerasan fisik maupun verbal yang dimaksud menjewer, mencubit, menendang, memukul dengan tangan, memukul dengan benda, menghukum hingga jatuh sakit/pingsan, melukai dengan benda berbahaya, membandingkan dengan saudara/anak lain, membentak dengan suara keras dan kasar, menghina dihadapan orang lain, menyebut bodoh, nakal, mencap dengan sebutan jahat dan sebagainya.

Upaya-upaya pemerintah yang telah dilakukan untuk mewujudkan sekolah ramah anak, dengan mengadakan beberapa program yang diselenggrakan oleh kementerian/lembaga berbasiskan sekolah maupun program inovatif. Program-program yang telah dilaksanakan terutama yang melibatkan PAUD adalah sekolah adiwiyata diselenggarakan oleh Kementerian Lingkungan Hidup bekerjasama dengan Kementerian Pendidikan (kemendikbud), sekolah inklusif dan sekolah dasar bersih sehat yang diselenggarakan oleh Kemendikbud, Children Friendly School (CSF) diselenggrakan oleh UNICEF, sekolah sehat, Usaha Kesehatan Sekolah (UKS) diselenggrakan oleh kementrian kesehatan (Kemenkes), komunitas sekolah rumah/komunitas belajar mandiri, dan Indonesia Herritage Foundation (IHF).

Konsep sekolah ramah anak bukanlah membangun sekolah baru, namun menciptakan kondisi yang nyaman di sekolah bagi anak, dan hak anak mendapatkan pendidikan dan perlindungian terpenuhi. Hal ini dikarenakan sekolah menjadi rumah kedua anak setelah rumah mereka sendiri. Sekolah ramah anak implementasinya dengan mewujudkan lingkungan sekolah yang aman, bersih, sehat dan peduli serta berbudaya; anak terjamin terlindungi dari kekerasan dalam bentuk apapun selama dalam lingkungan sekolah, partisipasi anak dalam pengawasan, pembelajaran, kebijakan dan perencanaan didukung oleh sekolah. 


\section{KESIMPULAN}

Manejemen Sekolah Ramah Anak (SRA) PAUD Inklusi CKS dan All Kids secara umum sudah memenuhi ketentuan manajemen, namun masih memerlukan banyak pembenahan terutama di CKS. Pelaksanaan manajemen SRA PAUD Inklusi dikedua lembaga adalah sebagai berikut; pertama, kedua PAUD memiliki ciri khas masing-masing dalam melaksanakan manajemen PAUD inklusi menyesuaikan kondisi lembaga; kedua, manajemen PAUD inklusi ramah anak di CKS dalam proses mencari bentuk, sedangkan Rumah Belajar All Kids telah memiliki bentuk; ketiga, kendala dalam upaya mewujudkan SRA di Cendekia Kids Shool berbeda dengan di Rumah Belajar All Kids; keempat, kendala terbesar manajemen adalah kompetensi manajemen sumber daya manusia: kelima, kedua PAUD belum ada legalitas sebagai PAUD Ramah Anak, namun dalam implementasinya sudah layak sebagai PAUD inklusi yang ramah anak.

Tiga hal mendasar yang harus disiapkan SRA PAUD Inklusif adalah guru (brainware), pengembangan kurikulum (software), serta sarana dan prasarana (hardware). Ketiganya perlu manajemen untuk bisa menciptakan lingkungan belajar yang bisa mendukung perkembangan anak. Lembaga PAUD inklusi sebenarnya sudah menerapkan sekolah ramah anak meskipun belum ada pernyataan secara tertulis sebagai sekolah ramah anak. Kendala dalam implementasi SRA PAUD Inklusi adalah belum adanya model dan pendampingan secara intensif dan berkelanjutan.

\section{DAFTAR PUSTAKA}

Baharun, H., \& Awwaliyah, R. (2018). Pendidikan Inklusi bagi Anak Berkebutuhan Khusus dalam Perspektif Epistemologi Islam. MODELING: Jurnal Program Studi PGMI, 5(1), 57-71.

Boddy, D. (2008). Management in Introduction. England: Pearson Education Limited.

Friend, M., \& Bursuck, W. D. (2015). Menuju Pendidikan Inklusi; Panduan Praktis untuk Mengajar. Yogyakarta: Pustaka Pelajar.

Gustiana, A. D. (2019). Kesiapan Menuju PAUD Ramah Anak. Edutech, 18(1), 58-66.

Hasan Agus R, A. (2016). Pendidikan Karakter berbasis Brain Based Education. Jurnal Pedagogik, 3(2), 13-23.

Husaini Usman. (2011). Manajemen Teori, Praktek dan Riset Pendidikan. Jakarta: PT Bumi Aksara.

Jansson, M., Sundevall, E., \& Wales, M. (2016). The Role Of Green Spaces And Their Management In A Child-Friendly Urban Village. Urban Forestry and Urban Greening, 18, 228-236.

Kementerian Pemberdayaan Perempuan dan Perlindungan Anak. (2015). Panduan Sekolah Ramah Anak. Jakarta: Deputi Tumbuh Kembang Anak.

Mandiudza, L. (2013). Child Friendly Schools. Greener Journal of Education Research, 3(6), 283-288. 
Mirawati, Sunanih, \& Dewi, R. S. (2018). PPTBK Guru PAUD dalam Pembuatan APE bagi Anak Usia Dini sebagai Upaya Peningkatan Sarana dan Prasarana yang Ramah Bagi Anak. Prosiding Seminar Nasional, 88-96. Yogyakarta: Universitas Ahmad Dahlan.

Misnatun. (2006). Pola Pembentukan Karakter Anak Melalui Pendidikan Ramah Anak dalam Perspektif Pendidikan Islam. Tadarus: Jurnal Pendidikan Islam, 5(2), 1-19.

Muazza, M., Hadiyanto, H., Heny, D., Mukminin, A., Habibi, A., \& Sofwan, M. (2018). Analisis Kebijakan Pendidikan Inklusi: Studi Kasus di Sekolah Dasar Jambi. Jurnal Kependidikan: Penelitian Inovasi Pembelajaran, 2(1), 1-12.

Muitasari, S. (2016). Implementasi Program Sekolah Ramah Anak dalam Mengembangkan Kecakapan Hidup (Studi Pendampingan Anak Korban Kekerasan di Yayasan Setara). Semarang: Universitas Negeri Semarang.

Munif, M. (2016). Pengembangan Pendidikan Agama Islam sebagai Budaya Sekolah. Jurnal Pedagogik, 3(2), 46-57.

Ndari, S. S., \& Chandrawaty., C. (2019). Peran Guru dan Orangtua dalam Implementasi Sekolah Ramah Anak tanpa Kekerasan melalui Parenting di PAUD Bintang dan PAUD Rumahku. Prosiding Kolokium Doktor dan Seminar Hasil Penelitian Hibah, 1(1), 480-496.

Nuraeni, L., Andrisyah, A., \& Nurunnisa, R. (2019). Efektivitas Program Sekolah Ramah Anak dalam Meningkatkan Karakter Anak Usia Dini. Jurnal Obsesi : Jurnal Pendidikan Anak Usia Dini, 4(1), 20-29.

Putri, A., \& Akmal. (2019). Sekolah Ramah Anak: Tantangan dan Implikasinya Terhadap Pemenuhan Hak Anak. Journal of Civic Education, 2(4), 228-235.

Rahim, A. (2016). Pendidikan Inklusif sebagai Strategi dalam Mewujudkan Pendidikan untuk Semua. Jurnal Pendidikan Ke-SD-an, 3(1), 68-71.

Rahmawati, A. T. H. (2019). Sekolah Ramah Anak Era Revolusi Industri 4.0 di SD Muhammadiyah Pajangan 2 Berbah Yogyakarta. Al-Bidayah: Jurnal Pendidikan Dasar Islam, 11(1), 49-76.

Sholeh, M. (2017). Kajian Kritis tentang Standar Nasional Pendidikan (SNP) Kajian. Al-Tanzim: Jurnal Manajemen Pendidikan Islam, 1(1), 36-55.

Siska, Y. (2018). Implementasi Nilai Pendidikan Karakter di Sekolah Dasar Negeri 4 Kotakarang Bandarlampung. Prosiding Seminar dan Diskusi Pendidikan Dasar, 31-37. Jakarta: Universitas Negeri Jakarta.

Subur, Muhammad Nanang Qosim, I. N. (2018). Implementasi Sekolah Ramah Anak dalam Membentuk Budaya Sekolah di SDN Geger Tegalrejo. Prosiding Konferensi Nasional Ke- 7, 353-357. Asosiasi Program Pascasarjana Perguruan Tinggi Muhammadiyah Aisyiyah (APPPTMA).

Suyadi, \& Ulfa, M. (2013). Konsep Dasar PAUD. Bandung: Remaja Rosdakarya.

Tirtayani, L. A. (2017). Upaya Pendampingan Anak Berkebutuhan Khusus pada Lembaga-lembaga PAUD di Singaraja Bali. Proyeksi, 12(2), 21-34.

Utami, R. D., Kurniasih, M., \& Kartikasari, F. N. (2017). Implementasi Penerapan Sekolah Ramah Anak pada Penyelenggaraan Pendidikan Sekolah Dasar. The 5th Urecol Proceeding, 170-176. Yogyakarta: Universitas Ahmad Dahlan. 
Wuryandani, W., \& Senen, A. (2018). Implementasi Pemenuhan Hak Anak melalui Sekolah Ramah Anak. Jurnal Civics: Media Kajian Kewarganegaraan, 15(1), 86-94.

Yulianto, A. (2016). Pendidikan Ramah Anak: Studi Kasus SDIT Nur Hidayah Surakarta. At-Tarbawi: Jurnal Kajian Kependidikan Islam, 1(2), 137-156.

Zumaroh, S., \& Widodo, W. (2018). Pendidikan Ramah Anak berbasis Kurikulum Syariah di SD Muhammadiyah Program Khusus Kota Barat Surakarta. Edudeena, 2(2), 173-179. 